\section{PERSEPSI DAN PARTISIPASI MASYARAKAT TERHADAP PROGRAM KELUARGA BERENCANA \\ (Penelitian di Desa Panggungharjo, Kec. Sewon, Kab. Bantul)}

Oleh: Taat Wulandari²

Abstracts

This research's goal is to learn on the development of the Family Planned program in the village after these years; various participations from people including village leaders (formal and non-formal), cadres and Family Planned participants, husbands and young people. Villager's perception, which consists of viewpoint and behavior of the leaders, cadres, husbands, and the young people to the Family Planned program and its advantage in the village during these years.

This research was using the method of descriptive qualitative. This research is meant to reveal various qualitative information with detail and meaningful analysis-descriptive, however does not ignore the quantitative information in the form of number nor amount. In each project will be seen the tendency, the pattern of thinking, disorder, behavior and the integration in genetic study of case. As mentioned previously, this research is using the strategy of case study. This type of strategy of with more specific details is called embedded case study research.

The results of this research show that after all these years, the Family Planned program in Pangggungharjo village was routinely held and or even more has been the tradition in society; to the Family Planned program, the perception of society, leaders and also health experts are positive therefore they highly participate. However, the forms of participations are limited to their understanding of the Family Planned program. The most highly participated people are those Family Planned program's participants themselves. While the participation of the Health Center's officers are by serving the program, leaders and cadres are limited to invite to join and facilitate the program. The relation of perception and

${ }^{1}$ Judul merupakan hasil penelitian kelompok dengan biaya dari DIKTI pada tahun 2007

2 Staf pengajar jurusan pendidikan sejarah FISE UNY

DIMENSIA, Volume 2, No. 1, Maret 2008 participation is strong mostly because of the economic, social and culture background. The characteristic of simple life also put simple behavior in their daily life.

Keywords: Family Planned, Participation, Perception

\section{A. Pendahuluan}

Merencanakan dan mengatur keluarga adalah soal kemanusiaan yang sekarang ini sedang diusahakan pelaksanaannya oleh pemerintah dan rakyat Indonesia. Kalau pembangunan itu adalah pembangunan manusia, maka kelahiran manusia itupun harus diatur. Pengaturan itu harus diadakan, agar supaya kenaikan produksi tidak dikalahkan oleh kenaikan kelahiran anak. Hal yang ditakutkan itupun terjadi pada masa sekarang ini, dimana kelahiran anak mengalahkan kenaikan produksi terutama produksi pangan. Di samping itu pertumbuhan penduduk yang tidak disertai dengan pertumbuhan yang cukup dalam produksi nasional dapat juga menimbulkan berbagai masalah yang berkaitaan dengan kurangnya fasilitas pendidikan, kurangnya penyediaan makanan, pelayanan kesehatan, kesempatan kerja, dan lain sebagainya. Usaha perencanaan keluarga harus dilakukan sedemikian rupa supaya tidak bertentangan dengan hukum yang berjalan dinegeri ini, juga tidak bertentangan dengan ajaran agama yang merupakan sumber rasa susila dan rasa peri kemanusiaan. Ini semua harus diatur oleh pemerintah dan harus didukung pula oleh segenap rakyat

Suksesnya suatu program dalam hal ini program keluarga berencana, tergantung dari aktif atau tidak aktifnya partisipasi masyarakat untuk mensukseskan program tersebut. Sehingga dalam posisi ini peran aktif masyarakat sangat penting artinya bagi kelancaran dan keberhasilan program tersebut dan tercapainya tujuan secara mantap. Program Keluarga Berencana dicanangkan dalam rangka usaha pemerintah untuk membangun manusia Indonesia yang berkualitas. Pada dasarnya pemerintah berkeinginan untuk membuat perubahan dari suatu kondisi tertentu ke keadaan lain yang lebih bernilai. Agar proses perubahan itu dapat 
menjangkau sasaran-sasaran perubahan keadaan yang lebih baik dan dapat digunakan sebagai pengendali masa depan, di dalam melaksanakan pembangunan itu perlu sekali memperhatikan segi manusianya. Karena dalam arti proses, pembangunan itu menyangkut makna bahwa manusia itu obyek pembangunan dan sekaligus subyek pembangunan. Sebagai subyek pembangunan manusia harus diperhitungkan, sebab dia punya nilai dan potensi yang luar biasa. Oleh karena itu, di dalam pembangunan perlu sekali mengajak subyek tadi untuk ikut berpartisipasi aktif dalam proses pembangunan secara berkelanjutan (Pasaribu dan Simanjntak, 1986: $62)$.

Kaitannya dengan peran serta masyarakat dalam program tertentu, peranan tokoh masyarakat baik formal maupun non-formal sangat penting terutama dalam mempengaruhi, memberi contoh, dan menggerakkan keterlibatan seluruh warga masyarakat di lingkungannya guna mendukung keberhasilan program. Apalagi di masyarakat pedesaan, peran tersebut menjadi faktor determinan karena kedudukan para tokoh masyarakat masih sangat kuat pengaruhnya, bahkan sering menjadi tokoh panutan dalam segala kegiatan hidup sehari-hari warga masyarakat. Persepsi warga masyarakat terhadap program tertentu merupakan landasan atau dasar utama bagi timbulnya kesediaan untuk ikut terlibat dan berperan aktif dalam setiap kegiatan program tersebut. Makna positif atau negatif sebagai hasil persepsi seseorang terhadap program akan menjadi pendorong atau penghambat baginya untuk berperan dalam kegiatannya.

Berbagai hal yang terjadi dan menjadi pengalaman yang kurang menyenangkan sering mengakibatkan warga masyarakat kurang mampu bersikap terbuka untuk secara jujur menyatakan persepsi dan pandangannya tentang suatu program yang diselenggarakan pemerintah. Karena sering dilandasi oleh persepsi yang kurang positif maka keterlibatan yang ada sering merupakan partisipasi semu. Keadaan yang demikian itu bila sering terjadi maka akan berakibat kurang lancarnya kegiatan sesuaii dengan rencana sehingga menyulitkan usaha pencapaian tujuan program secara utuh dan mantap (Sutopo, 1996: 132). Hambatan yang sering muncul ketika psrtisipasi masyarakat terhadap suatu program pemerintah kurang maksimal bisa secara internal, berupa hambatan sosiokultural, dan eksternal, hambatan dari birokrasi pemerintah (Miftah Thoha,tth: 11-17)

Hambatan internal, merupakan hambatan dari dalam masyarakat itu sendiri, yang merupakan keengganan sebagian besar warga masyarakatuntuk terlibat langsung dalam suatu program kegiatan. Hal ini disebabkan karena keadaan sosio-kultural mereka yang belum memungkinkan untuk secara aktif menyuarakan keinginan mereka. Sementara mereka lebih memilih diam. Hambatan ini bukanlan merupakan hambatan yang fatal, sebab hamabatan ini masih bisa diperbaiki dengan cara memberikan masukan informasiinformasi baru yang positif dan bersifat membangun. Mereka harus dikenalkan dengan penemuan-penemuan dan perkembangan baru di daerah lain, yang nantinya akan membuka cakrawala berpikir mereka. Akan tetapi kadang-kadang mereka masih memiliki kesadaran yang rendah karena adanya beberapa keterbatasan. Misalnya: rendahnya pendidikan, rendahnya sosial-ekonomi, kurangnya sarana dan prasaranan.

Sedangkan hambatan yang sifatnya eksternal adalah karena selama ini setiap ada program pemerintah biasanya sistemnya sendiri yang lebih menekankan perencanaan dari atas (top-down) atau strategi center-down, yang kurang memperhatikan masyarakay arus bawah. Akibatnya, yang dilakukan itu kadang-kadang menjadi tidak realistis dan mengalami stagnasi. Akibatnya juga banyak program menghadapi kendala dalam pelaksanaannya seperti kendala yang telah diuraikan di atas. Sehingga partisipasi warga masyarakat sangat kurang.

Proses dan persepsi seseorang tidak mudah diungkap secara lengkap dan rinsi, lebih-lebih apabila orang tersebut tidak bersikap terbuka. Banyak hal yang merupakan pengalaman seseorang dapat mempengaruhi makna hasil persepsi terhadap kegiatan hubungan antar manusia dalam masyarakat. Selain tergantung dari bentuk dan proses interaksinya, persepsi seseorang sangat tergantung pada 
banyak faktor yang membentuk pengalamannya dalam kehidupan masyarakat itu sendiri. Dalam kaitannya dengan program Keluarga Berencana sebagai usaha pemerintah mewujudkan masyarakat adil dan makmur, materiil, dan spirituil sesuai dengan tujuan pokok yang dirumuskan dalam pembahasan dan batang tubuh UUD 45, maka partisipasi aktif warga masyarakat juga akan sangat ditentukan oleh persepsinya terhadap program Keluarga Berencana yang sangat dipengaruhi oleh latar belakang sosial ekonomi dan budayanya yang khusus.

Penelitian ini akan mengambil Desa Panggungharjo Kecamatan Sewon Kabupaten Bantul Daerah Istimewa Yogyakarta sebagai wilayah kajiannya. Sebagai satu wilayah yang dapat dikatakan daerah perbatasan / daerah sub-urban antara desa dengan kota, karena wilayah tersebut terletak di Kabupaten Bantul paling Utara berbatasan dengan wilayah kota paling selatan. Jumlah orang yang masuk/migrasi di wilayah ini terlihat sangat tinggi sehingga sangat berpengaruh terhadap jumlah penduduk. Dan hal tersebut tentunya akan berdampak begi sektor kehidupan lain. Hal yang kadang-kadang tidak terungkap adalah bagaimana kaitan antara semakin banyaknya penduduk dengan persepsi dan partisipasi masyarakat terhadap program Keluarga Berencana?

Berdasarkan gambaran permasalahan pada latar belakang masalah di atas, maka permasalahan yang akan dikaji dalam penelitian ini adalah (1) Bagaimana perkembangan pelaksanaan kegiatan program Keluarga Berencana selama ini di desa? (2) Bagaimana persepsi warga masyarakat desa terhadap program Keluarga Berencana? (3) Bagaimana bentuk-bentuk partisipasi masyarakat pada program Keluarga Berencana di desa selama ini? (4) Sejauh mana persepsi dan partisipasi masyarakat desa berkaitan dengan kondisi sosial, ekonomi, dan budayanya?

\section{B. Persepsi dan Partisipasi Masyarakat}

Menurut Davidoff, persepsi merupakan cara kerja atau proses yang rumit dan aktif, karena tergantung pada sistem sensorik dan otak (Davidoof, 1988: 237). Bagi manusia, persepsi merupakan suatu kegiatan yang pleksibel, yang dapat menyesuaikan diri secara baik terhadap masukan yang berubah-ubah. Dalam kehidupan sehari-hari, tampak bahwa persepsi manusia mempunyai kemampuan menyesuaikan diri dengan baik terhadap lingkungan dan budayanya. Dengan demikian pengalaman seseorang yang merupakan akumulasi dari hasil berinteraksi dengan lingkungan hidupnya setiap kali dalam masyarakat, lokasi geografisnya, latar belakang sosial-ekonomi-politiknya, keterlibatan religiusnya, sangat menentukan persepsinya terhadap suatu kegiatan dan keadaan.

Karena kebudayaan dinyatakan sebagai segala sesuatu yang berhubungan erat dengan perilaku manusia dan kepercayaan, maka ia meliputi berbagai hal dalam kehidupan manusia, yang diantaranya adalah agama, pendidikan, struktur sosial ekonomi, pola kekeluargaan, kebiasaan mendidik anak, dan sebagainya. Dengan demkian dapat dikatakan bahwa kondisi kehidupan seseorang sehari-harinya sangat mempengaruhi persepsi pada setiap peristiwa sosial, dimana dalam setiap kegiatan sosial tersebut selalu melibatkan hubungan antar-subjek dan terbentuknya makna. Makna tersebut akan menentukan kesanggupan seseorang untuk terlibat dan berpartisipasi pada kegiatan tertentu dalam masyarakatnya (Sutopo, 1996: 133).

Dalam Kamus Besar Bahasa Indonesia, persepsi diintepretasikan sebagai tanggapan atau penerimaan langsung dari sesuatu, atau proses seseorang mengetahui beberapa hal melalui panca inderanya (Depdikbud, 1995:759). Persepsi selalu berkaitan dengan pengalaman dan tujuan seseorang pada waktu terjadinya proses persepsi. Ia merupakan tingkah laku selektif, bertujuan, dan merupakan proses pencapaian makna, dimana pengalaman merupakan faktor penting yang menentukan hasil persepsi (Sutopo, 1996:133). Tingkah laku selalu didasarkan pada makna sebagai hasil persepsi terhadap kehidupan para pelakunya. Apa yang dilakukan, dan mengapa seseorang melakukan berbagai hal, selalu didasarkan pada batasan-batasan menurut pendapatnya sendiri, dan dipengaruhi oleh latar belakang budayanya yang khusus (Spradly, 1980:137).

DIMENSIA, Volume 2, No. 1, Maret 2008 
Dari teori-teori di atas, dapat dikemukakan bahwa persepsi merupakan proses aktif, dimana masing-masing individu menganggap, mengorganisasi, dan juga berupaya untuk mengintepretasikan yang diamatinya secara selektif. Oleh karena itu, persepsi merupakan dinamika yang terjadi dalam diri seseorang pada saat ia menerima stimulus dari lingkungan dengan melibatkan indra, emosional, serta aspek kepribadian lainnya. Dalam proses persepsi itu, individu akan mengadakan penyeleksian, apakah stimulus individu berguna atau tidak baginya, serta menentukan apa yang terbaik untuk dikerjakannnya.

Dalam kajian ini, persepsi masyarakat terhadap program Keluarga Berencana, tidak hanya dilihat sebagai proses penerimaan stimulus dari luar dirinya, tetapi juga sikap batin yang mengarahkan seseorang mampu melihat hakekat yang terdalam dari urgensi pelaksanaan program Keluarga Berencana yang diselenggarakan oleh pemerintah yang lebih bermakna. Persepsi positif masyarakat terhadap program Keluarga Berencana, akan sangat menentukan kesanggupan mereka untuk terlibat dan berpartisipasi secara aktif dalam pelaksanaan program Keluarga Berencana secara berkesinambungan. Partisipasi itu sendiri, menurut Purwodarminto, adalah suatu kegiatan atau turut berperan serta dalam suatu program kegiatan (Purwodarminto, 1984: 453).

Partisipasi merupakan proses aktif yang mengkondisikan seseorang turut serta dalam suatu kegiatan yang disebabkan oleh persepsi yang positif. Meskipun demikian, partisipasi juga sangat dipengaruhi oleh kondisi sosiologis-ekonomis-politis seseorang yang merupakan latar belakang budaya yang berbeda-beda. Oleh karena itu, partisipasi masyarakat juga dapat berbeda-beda bentuknya. Tetapi dalam penelitian ini akan digambarkan secara komprehensif tampilan persepsi dan partisipasi dari masyarakat dalam studi kasus penelitian ini.

\section{Metode Penelitian}

Berdasarkan permasalahan yang diajukan dalam penelitian ini, yang lebih mengutamakan pada masalah proses dan

pada masalah proses dan

makna/persepsi, maka jenis penelitian dengan strateginya yang cocok dan relevan adalah penelitian kualitatif deskriptif. Dengan penelitian ini diharapkan dapat mengungkap berbagai informasi kualitatif dengan deskripsi-analisis yang teliti dan penuh makna, yang juga tidak menolak informasi kuantitatif dalam bentuk angka maupun jumlah. Pada tiap-tiap obyek akan dilihat kecenderungan, pola pikir, ketidakteraturan, serta tampilan perilaku dan integrasinya sebagaimana dalam studi kasus genetik (Muhadjir, 1996: 243).

Strategi yang digunakan dalam penelitian ini adalah studi kasus (case study). Karena permasalahan dan fokus penelitian sudah ditentukan dalam proposal sebelum terjun ke lapangan, maka jenis strategi penelitian ini secara lebih spesifik dapat disebut sebagai studi kasus terpancang (embedded case study research)(Yin, 1987: 136). Data yang paling penting untuk dikumpulkan dan dikaji dalam penelitian ini adalah data kualitatif. Data kualitatif tidak bersifat nomotetik (satu data satu makna) seperti dalam pendekatan kuantitatif atau positivisme. Untuk itu, data-data kualitatif perlu ditafsirkan agar mendekati kebenaran yang diharapkan (Waluyo, 2000: 20). Adapun jenis sumber data yang digunakan dalam penelitian ini meliputi: Informan atau nara sumber yang terdiri dari para pelaksana program KB di Desa Panggungharjo Sewon Bantul, tempat dan aktivitas program KB yang diselenggarakan oleh BKKBN di Desa Panggungharjo Sewon Bantul sebagaimana studi kasus dalam penelitian ini, teks yang berupa arsip dan dokumen resmi mengenai program $\mathrm{KB}$, jadwal kegiatan program, foto-foto situs studi kasus, dan catatan-catatan lain yang relevan.

Data diperoleh melalui wawancara mendalam, observasi langsung, dan mencatat Dokumen (Content Analysis). Teknik cuplikan yang akan digunakan dalam penelitian ini adalah "Purposive Sampling" (Sutopo, 1996 : 138), atau lebih tepat disebut sebagai cuplikan dengan criterion-based selection yang tidak didapat ditemukan lebih dulu secara acak. (Moleong, 1999:165-166). Dalam hal ini peneliti memilih informan yang dianggap "mengetahui permasalahan yang dikaji" (dapat dipercaya informasinya). 
Untuk menjamin validitas data yang akan dikumpulkan dalam penelitian ini, peneliti mengggunakan teknik informant review atau umpan balik dari informan (Milles dan Hubberman, 1992:453). Selain itu peneliti juga menggunakan teknik triangulasi untuk lebih memvalidkan data (Paton, 1980: 100). Teknik triangulasi yang penulis gunakan dalam penelitian ini adalah triangulasi sumber, triangulasi metode, dan triangulasi teori. Pertama, triangulasi sumber, yakni mengumpulkan data sejenis dari beberapa sumber data yang berbeda. Dalam hal ini, untuk memperoleh data tentang persepsi masyarakat terhadap program $\mathrm{KB}$, dikumpulkan dari hasil wawancara dengan petugas BKKBN pelaksana program, tokoh masyarakat dan warga masyarakat. Kedua, triangulasi metode, yakni mengumpulkan data yang sejenis dengan menggunakan teknik atau pengumpulan data yang berbeda. Dalam hal ini untuk memperoleh data, maka digunakan beberapa sumber dari hasil wawancara dan observasi. Ketiga, triangulasi teori untuk mengintepretasikan data yang sejenis. Data tentang persepsi misalnya, digali dari beberapa teori tentang persepsi, partisipasi, dan psikologis

Teknik analisis yang digunakan dalam penelitian ini adalah analisis interaktif (Miles dan Huberman, 1984). Dalam model analisis ini, tiga komponen analisisnya yaitu reduksi data, sajian data, dan penarikan kesimpulan atau verivikasi, aktivitasnya dilakukan dalam bentuk interaktif dengan proses pengumpulan data sebagai suatu proses yang berlanjut, berulang, dan terus-menerus hingga membentuk sebuah siklus. Dalam proses ini aktivitas peneliti bergerak di antara komponen analisis dengan pengumpulan data selama proses ini masih berlangsung. Selanjutnya peneliti hanya bergerak diantara tiga komponen analisis tersebut.

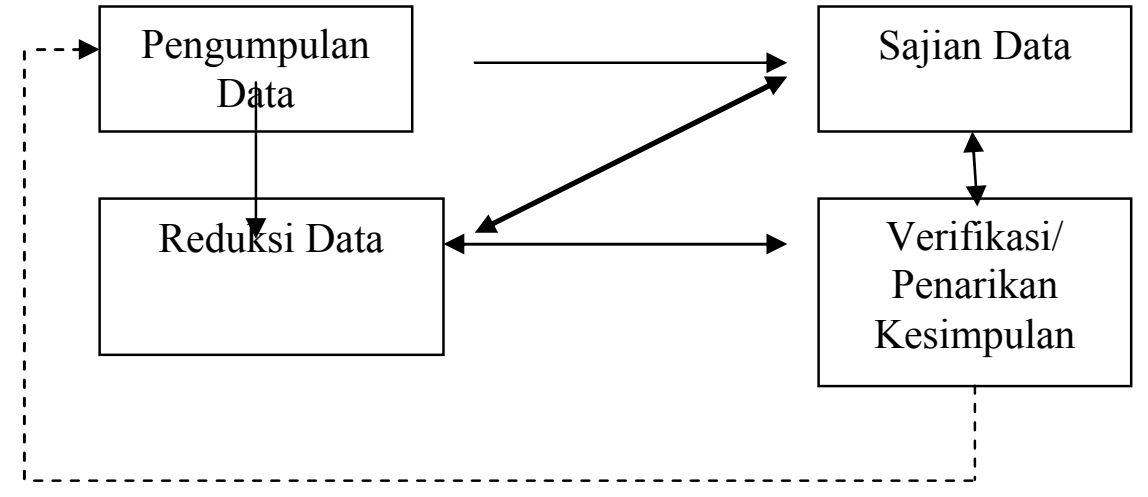

Gambar 1. Model Analisis Interaktif Milles dan Hubberman

\section{Hasil dan Pembahasan}

1. Deskripsi Data Umum

Desa Panggungharjo berada di bawah wilayah Kecamatan Sewon Bantul Daerah Istimewa Yogyakarta. Secara geografis, Desa Panggungharjo memiliki wilayah perbatasan dengan Kodya Yogyakarta sebelah utara, Desa Timbulharjo sebelah selatan, Desa Tirtonirmolo sebelah barat, dan Desa Bangunharjo sebelah timur. Desa panggungharjo memiliki luas wilayah 560,9660 hektar, dengan ketinggian tanah dari permukaan laut $45 \mathrm{~m}$, banyaknya curah hujan $2.233 \mathrm{~mm} /$ th, suhu udara 28 derajat celcius dengan tofografi dataran rendah. Untuk jalan seluas 24.0331 ha, sawah dan ladang seluas 301.7860, pemukiman atau perumahan seluas 190.9130 ha, pemakaman seluas 7.8500 ha, dan yang lainnya seluas 6.1409 ha.

Aksesbilitas Desa Panggungharjo, menunjukkan bahwa jarak dari pusat kecamatan adalah $2 \mathrm{~km}$, jarak dari ibu kota kabupaten adalah $8 \mathrm{~km}$, jarak dari ibukota provinsi adalah $7 \mathrm{~km}$, dan jarak dari ibu kota negara adalah $500 \mathrm{~km}$. Keadaan penduduk menurut jenis kelamin adalah laki-laki sebanyak 12.864 orang dan perempuan 12274 orang dengan jumlah kepala keluarga 7885 orang. Dalam hal keagamaan, sebanyak 23.873 
beragama Islam, 529 beragama Kristen, 564 Katolik, 43 Hindu, dan Budha 37 orang.

Jumlah penduduk Desa Panggungharjo menurut tingkat pendidikan dengan lulusan pendidikan umum TK sebanyak 3.968 orang; SD 4.507 orang; SMP 3.762 orang; SLTA 8.691 orang; Sarjana Muda 794 orang; dan Sarjana S1-S3 1.061 orang. Sedangkan lulusan pendidikan khusus: Pondok Pesantren 234 orang; Madrasah 238 orang; Pendidikan keagamaan 220 orang; SLB 5 orang; dan kursus 66 orang. Sedangkan jumlah penduduk menurut mata pencaharian: PNS 601 orang; TNI 53 orang; Polri 79 orang; karyawan swasta 6.961 orang. Sedangkan yang wiraswasta ada 579 orang; tani 769 orang; buruh ada 6.635 orang; buruh tani 221 orang; pensiunan 208 orang; jasa 101 orang; dan lain-lain ada 1.282 orang. Sedangkan dalam hal organisasi sosial dan kemasyarakatan jenis organisasi sosial seperti yayasan dan lain sebagainya ada 15 buah; organisasi kemasyarakatan ada 18 buah; tokoh masyarakat san politik ada 290 orang dan organisasi profesi ada 2 buah.

Dalam hal sarana peribadatan, Panggungharjo memiliki 23 buah mesjid, 42 mushola dan 1 buah puskesmas dan 1 puskesmas pembantu, 1 buah RSU Swasta, 2 buah RS Bersalin, 1 poliklinik Balai Pelayanan Masyarakat, 10 buah Sekolah Dasar, 1 buah SMP, 3 buah pondok pesantren, 2 buah madrasah, dan 1 buah Universitas/Institut. Dalam program Keluarga Berencana yang merupakan program nasional rincian jumlah akseptor KELUARGA BERENCANA adalah sebagai berikut. PIL 393 orang, IUD 400 orang, Suntik 1200 orang, Kondom 225 orang, MOW 210 orang, MOP 50 orang, dan KELUARGA BERENCANA mandiri 665 orang. Sementara tenaga dokter ada 2 orang, tenaga perawat 4 orang, dan tenaga bidan orang, serta dukun bayi ada 6 orang. Sedangkan dokter praktek ada 8 orang, dokter gigi ada 7 orang, dan dokter mata ada 1 orang.

Dalam sistem kepemerintahan, pola struktur pemerintahan Desa Panggungharjo terdiri atas Kepala Desa dan Badan Permusyawaratan Desa. Dalam melaksanakan tugasnya, kepala desa dibantu oleh perangkat desa yang terdiri atas: Sekretaris Desa, Kepala Urusan, dan Kepala Dukuh. Jumlah seksi ada 7 buah, Pokgiat pedukuhan ada 14 buah, jumlah pengurus LMPD ada 28 orang, jumlah RT ada 107 RT, dan pengurus RT ada 642 orang. Di samping itu, desa juga memiliki Tim Penggerak PKK dimana jumlah pokja TP PKK desa ada 4 buah, dan jumlah pengurus TP PKK ada 43 orang. Tugas Tim Penggerak PKK adalah untuk membantu masyarakat dalam rangka meningkatkan keterampilan dan kesejahteraan anggota keluarga. Kaitannya dengan penelitian ini, yakni pelaksanaan program Keluarga Berencana, maka peran besar Tim Penggerak PKK cukup besar dalam hal menggerakkan seluruh warga masyarakat untuk ikut berpartisipasi secara aktif dalam program Keluarga Berencana untuk kepentingan keluarga masing-masing dalam rangka mewujudkan keluarga kecil yang bahagia. Demikian pula dengan peran tokoh masyarakat dan tenaga medis sangat berpengaruh terhadap keberhasilan pelaksanaan program.

2. Pembahasan dan Analisis

Sebagaimana telah diuraikan dalam deskripsi data umum mengenai kondisi geografi dan demografi penduduk Panggungharjo, maka masalah perekonomian juga sangat dipengaruhi oleh kondisi tersebut. Kebanyakan masyarakat hidup dari lahan pertanian yakni padi. Selain itu juga ada yang menanam tebu. Namun demikian, untuk mempertahankan kehidupan sehari-hari, maka mereka juga bekerja sambilan seperti halnya kerajinan, berdagang, menjadi buruh, dan pekerjaan-pekerjaan lain yang dapat menghasilkan uang. Pola bertahan hidup mereka menunjukkan keanekaragaman pencerminan yang menggambarkan karakteristik yang unik sebagai penduduk yang mendiami wilayah yang cukup menantang kehidupan. Apalagi setelah terjadi gempa bumi 27 mei 2006 lalu, kondisi dan struktur sosial masyarakat Panggungharjo porakporanda, dan bahkan banyak yang 
meninggal dunia. Suatu hal yang agak unik adalah jumlah ibu hamil pasca gempa melonjak secara tajam.

Dalam kegiatan Keluarga Berencana, banyak komponen atau elemen yang terlibat baik secara langsung maupun tidak langsung. Pada dasarnya, masyarakat siap dalam melaksanakan program Keluarga Berencana yang telah menjadi program pemerintah. Masyarakat berperan serta dalam mengikuti kegiatan program Keluarga Berencana. Namun demikian, tingkat keberhasilan program akan sangat tergantung pada ketercapaian tujuan oleh realitas implementasi di lapangan. Sejauh mana penerimaan masyarakat terhadap kegiatan program tersebut, akan sangat dipengaruhi oleh ketepatan sasaran program Keluarga Berencana. Berdasarkan pengamatan langsung, maka tampaknya ketercapaian tujuan program tersebut masih perlu dijadikan perhatian mengingat masih lemahnya kontrol program terpadu ini.

Tonggak pertama yang penting dalam perkembangan program nasional $\mathrm{KB}$ di Indonesia adalah kepeloporan Perkumpulan Keluarga Berencana Indonesia (PKBI), yang mulai mengadakan aktivitasnya pada tahun 1957. Pada kurun waktu 1950-an permasalahan KB masih sangat sensitif. Sebagai contoh seorang dokter wanita yang memberikan penyuluhan tentang KB melalui radio di Yogyakarta pada tahun 1952. Masyarakat banyak yang melakukan protes-protes melalui surat-surat maupun majalah harian. Dalam suatu pertemuan yang disponsori oleh suatu organisasi wanita di Yogyakarta, Oktober 1952, yang juga dihadiri oleh beberapa tokoh agama, diputuskan bahwa penggunaan kontrasepsi tidak dapat disetujui.

Terdapat beberapa peristiwa penting pada tahun 1967. Pada awal tahun 1967, diselenggarakan simposium kontrasepsi di Bandung yang dihadiri oleh masyarakat luas dan media massa. Pada bulan Februari 1967 PKBI mengadakan kongres pertama yang mempunyai dampak luas. Pada bulan April 1967 dilancarkan proyek pertama di Indonesia, yakni proyek KB DKI Jakarta Raya. Dari situlah kemudian program KB mulai disosialisasikan hingga terbentuklah apa yang disebut Lembaga Keluarga Berencana Nasional (LKBN) pada tahun 1968, selanjutnya BKKBN pada tahun 1970.

BKKBN telah mengembangkan dengan baik suatu sistem monitoring yang menghasilkan service statistic. Berdasarkan data program tersebut, dengan mudah dapat diikuti perkiraan pencapaian prorgam dari bulan ke bulan, pencapaian terhadap target, pencapaian terhadap pasangan usia subur baik pada tingkat provinsi, maupun pada tingkat nasional. Juga terdapat angka pencapaian berdasarkan jenis kontrasepsi. Dalam perkembangan selanjutnya, program KB semakin mendapat tempat dalam masyarakat, meskipun pada awal perkembangannya menemui berbagai rintangan dan protes keras. Masyarakat semakin sadar akan pentingnya KB, tidak saja bagi dirinya dan keluarganya, melainkan pula bagi masyarakat lingkungan sosialnya maupun bangsa secara nasional.

Implementasi kegiatan program selama ini, tentunya banyak sekali faktor-faktor baik yang mendukung maupun yang menghambatnya. Tingkat pendidikan tenaga ahli dan masyarakat itu sendiri, keterlibatan penuh tokoh masyarakat, LSM, Tim Penggerak PKK, kepala desa dan perangkat desa, keterlibatan dasa wisma, serta komitmen pemerintah kabupaten, sangat berpengaruh terhadap tingkat keberhasilan program. Faktorfaktor inilah yang masih belum diperhatikan secara optimal, sehingga implementasi program sesuai dengan harapan yang ingin dicapai. Program KB ini meskipun secara relatif dapat dikatakan berhasil, namun hal ini harus terus dipantau dan menjadi program pemerintah secara berkelanjutan, agar pertumbuhan penduduk dapat sejalan dengan pertumbuhan sektor lainnya. Karena jika terjadi ledakan penduduk, maka akan menimbulkan masalah-masalah sosial yang semakin kompleks.

Setelah melalui proses reduksi, sajian data, dan verifikasi, maka dalam hal persepsi masyarakat, tenaga ahli kesehatan, dan para tokoh masyarakat terhadap pelaksanaan program Keluarga Berencana diinterpretasikan positif. Mereka 
menganggap penting dilaksanakannya program tersebut, tidak hanya sekedar melaksanakan program formal dan rutinitas belaka, melainkan juga substansinya yang besar bagi peningkatan kualitas kehidupan manusia, terutama yang menyangkut masalah kesehatan, kependudukan, dan masalah-masalah sosial lainnya termasuk dalam hal berkeluarga secara substantif. Dengan persepsi yang positif, maka partisipasinya dalam pelaksanaan kegiatan tersebut juga cukup tinggi. Namun demikian, tampaknya yang masih perlu diluruskan adalah pemahaman yang masih terlalu sederhana tentang program tersebut. Dalam pandangan masyarakat, program Keluarga Berencana adalah program rutin dan pribadi yang ditafsirkan tergantung keinginan personal. Pandangan ini masih terlalu sempit karena sebenarnya Keluarga Berencana tidak hanya untuk pelaksanaan program yang bersifat masalah pribadi atau keluarga, melainkan juga sebagai upaya pemerintah dalam penanganan masalah sosial dan kependudukan.

Adapun faktor-faktor yang mendorong masyarakat dalam berpartisipasi dalam kegiatan program tersebut adalah selain hal tersebut sudah menjadi tradisi dan bagian dari keyakinan mereka yang baru, kesehatan ibu juga menjadi perhatian utama. Namun sebagai penghambat pelaksanaan program tersebut adalah masih rendahnya tingkat pemahaman masyarakat, di samping itu juga para tenaga ahli kesehatan tidak memberikan pelayanan yang lebih responsif terhadap masyarakat. Hal ini juga salah satunya diakibatkan oleh masih rendahnya wawasan dan pendidikan para tenaga ahli. Sedangkan keterlibatan perangkat desa dalam pelakksanaan program ini adalah dengan memberikan fasilitas desa maupun dusun untuk pelaksanaan penyuluhan, di samping memberitahu ketika ada program KB yang sifatnya masal. Meskipun demikian, sebenarnya internalisasi terhadap program KB ini sudah mulai nampak beberapa dasa warsa terakhir. Hal tersebut muncul seiring dengan masalah kebutuhan pribadi yang menghendaki keluarga yang wajar, normal, dan tercukupi kebutuhan baik materiil maupun immateriil.

Sedangkan keterlibatan tokoh masyarakat dalam pelaksanaan program tersebut adalah dengan memberikan ceramah-ceramah atau penyuluhan terhadap masyarakat akan pentingnya program tersebut bagi kelangsungan kehidupan yang normal dan lebih baik. Masalah yang menyangkut berbagai macam jenis $\mathrm{KB}$ dan tingkat kecocokan merupakan tanggungjawab pelaksana program KB di tingkat masyarakat, sementara para tokoh masyarakat hanya menghimbau agar menggunakan jenis $\mathrm{KB}$ yang cocok dengan masing-masing individu. Karena jika dipaksakan menggunakan suatu jenis KB, padahal tidak cocok dengan kondisi tubuhnya, maka akan dihadapkan pada masalah kesehatan. Dengan demikian keterlibatan tokoh masyarakat meskipun tidak secara signifikan, namun mereka merupakan pendorong bagi proses internalisasi pelaksanaan program KB secara sukarela dan mandiri.

Kemudian dalam pandangan tenaga ahli kesehatan termasuk di dalamnya yang berperan dalam KB yakni BKKBN, masyarakat cenderung menerima dengan baik terhadap program tersebut. Masyarakat siap dalam merealisasikan program tersebut terutama mengenai keterlibatan Tim Penggerak PKK yang aktif dalam mendukung kegiatan tersebut. Para tenaga ahli juga menilai bahwa fasilitas masih perlu ditingkatkan, sehingga perlu diupayakan secara berkelanjutan, dan memenuhi aspek ketercukupan alat KB bagi masyarakat yang memerlukan. Para tenaga ahli juga melihat persepsi dan keterlibatan masyarakat cukup baik, sehingga program tersebut dapat terlaksana dengan baik dan tepat sasaran. Masyarakat cenderung menggunakan atau mengikuti program KB berdasarkan kesadaran pribadi, dengan tingkat penyalahgunaan tidak begitu banyak.

Dalam pada itu, hal lain yang masih berhubungan dengan kegiatan ini, para tokoh masyarakat juga cenderung melihat positif terhadap program itu. Dengan demikian, mereka juga secara tidak langsung terlibat juga dalam implementasi 
program. Dalam pada itu, para tokoh masyarakat melihat adanya karaktersistik ekonomi, pendidikan, budaya, dan sosial masyarakat sangat berpengaruh terhadap tingkat penerimaan program tersebut. Dengan tingkat kompleksitas karakteristik masyarakat yang masih sangat sederhana, maka realitas implementasi pogram juga dilaksanakan dalam kerangka kerja yang sederhana pula. Sangat jarang sekali dijumpai masyarakat yang gagal mengikuti KB karena alasan kekurangan ekonomi atau tidak mampu membeli alat $\mathrm{KB}$, meskipun tidak dapat dikatakan tidak ada. Alasan ekonomi yang mendorong adalah dengan kalkulasi jumlah keluarga dengan kemampuan ekonomi yang mendukungnya. Sehingga kepemilikian harta kekayaan atau ekonomi menunjang eksistensi keluarga. Dan tentunya jumlah keluarga kecil dan secara ekonomi tercukupi, adalah cerminan keberhasilan keluarga kecil bahagia atau KB Mandiri.

Di Desa Panggungharjo, pelaksanaan program Keluarga Berencana dilaksanakan secara personal maupun masal oleh petugas kesehatan bekerja sama dengan BKKBN dan Tim Penggerak PKK. Sebagaimana telah diuraikan di muka, maka pelaksanaan program Keluarga Berencana di Desa Panggungharjo juga dalam rangka untuk pembinaan keluarga. Hal ini diungkapkan oleh X1 dalam wawancara bahwa kegiatan dilaksanakan secara rutin masal atau perorangan. Begitu pula dengan penuturan X2 dan X3 yang setiap mengikuti program Keluarga Berencana dengan menggunakan KB Suntik tiap bulan. X2 juga mengungkapkan bahwa wawasan masyarakat tentang program Keluarga Berencana masih sangat sederhana, sehingga perlu adanya intensifitas pelaksanaan program sehingga substansi yang sesungguhnya dari program tersebut dapat tercapai. Untuk itu, maka diperlukan penyuluhan yang intens pula sehingga kesadaran masyarakat akan pentingnya program KB dapat terinternalisasi dengan baik. Dalam kesempatan lain Z1 memandang bahwa program penyuluhan lebih diperluas terhadap dampak sosial penyelenggaraan $\mathrm{KB}$ baik menyangkut masalah sosial, ekonomi, budaya, maupun masalah sosial lainnya. Begitu pula dengan Z2 juga memandang perlu hal tersebut.

Suksesnya suatu program dalam hal ini program Keluarga Berencana, tergantung dari aktif atau tidak aktifnya partisipasi masyarakat untuk mensukseskan program tersebut. Sehingga dalam posisi ini peran aktif masyarakat sangat penting artinya bagi kelancaran dan keberhasilan program tersebut dan tercapainya tujuan secara mantap. Program Keluarga Berencana dicanangkan dalam rangka usaha pemerintah untuk membangun manusia Indonesia yang berkualitas, sesuai dengan pertumbuhan penduduk yang mendukung program pembangunan. Menurut Z2, ledakan penduduk tidak saja akan menimbulkan masalah kemampuan sumber daya manusia, melainkan pula masalah sosial lain yang kompleks.

Pada dasarnya pemerintah berkeinginan untuk membuat perubahan dari suatu kondisi tertentu ke keadaan lain yang lebih bernilai. Agar proses perubahan itu dapat menjangkau sasaransasaran perubahan keadaan yang lebih baik dan dapat digunakan sebagai pengendali masa depan, di dalam melaksanakan pembangunan itu perlu sekali memperhatikan segi manusianya. Karena dalam arti proses, pembangunan itu menyangkut makna bahwa manusia itu obyek pembangunan dan sekaligus subyek pembangunan. Sebagai subyek pembangunan manusia harus diperhitungkan, sebab dia punya nilai dan potensi yang luar biasa. Oleh karena itu, di dalam pembangunan bangsa perlu melibatkan secara intensif subyek untuk ikut berpartisipasi aktif dalam pembangunan (Pasaribu dan Simanjutak, 1986: 62)

Suatu hambatan yang sering muncul ketika partisipasi masyarakat terhadap suatu program pemerintah kurang maksimal bisa secara internal, berupa hambatan sosio-kultural, dan eksternal, hambatan dari birokrasi pemerintah (Miftah Thoha,tth: 11-17). Hambatan internal, merupakan hambatan dari dalam masyarakat itu sendiri, yang merupakan keengganan sebagian besar warga masyarakat untuk terlibat langsung dalam 
suatu program kegiatan. Hal ini disebabkan karena keadaan sosio-kultural mereka yang belum memungkinkan untuk secara aktif menyuarakan keinginan mereka. Sementara mereka lebih memilih diam. Hambatan ini bukanlan merupakan hambatan yang fatal, sebab hamabatan ini masih bisa diperbaiki dengan cara memberikan masukkan informasi-informasi baru yang positif dan bersifat membangun. Mereka harus dikenalkan dengan penemuan-penemuan dan perkembangan baru di daerah lain, yang nantinya akan membuka cakrawala berpikir mereka. Akan tetapi kadang-kadang mereka masih memiliki kesadaran yang rendah karena adanya beberapa keterbatasan. Misalnya: rendahnya pendidikan, rendahnya sosial-ekonomi, kurangnya sarana dan prasarana, dan lain sebaginya.

Pengendalian pertumbuhan penduduk merupakan unsur penting dalam pembangunan ekonomi. Program Keluarga Berencana di Indonesia dapat berhasil karena ditopang oleh kemajuan pendidikan, peningkatan mobilitas penduduk, bertambahnya angkatan kerja, dan lain-lain. Tetapi, masalah internalisasi motivasi melaksanakan Keluarga Berencana tampaknya masih merupakan persoalan tersendiri. Masalah internalisasi motivasi melaksanakan Keluarga Berencana merupakan persoalan yang sentral. Berhubungan pendekatan selama ini adalah supply oriented di mana masyarakat didorong menggunakan fasilitas kesehatan dengan cuma-cuma lalu didukung oleh sistem target maka ketergantungan adalah produk dari strategi itu sendiri. (Masri Singarimbun, 1988: 15). Selama ini mereka yang mampu juga mendapat subsidi dalam bentuk layanan yang cuma-cuma. Diharapkan program Keluarga Berencana akan semakin meluruskan hal ini dan kemudian tertanam internalisasi motivasi implementasi Keluarga Berencana pada masyarakat secara keseluruhan. Apabila situasi tersebut telah menjadi kondisi naturalistik, maka tatanan sosial yang harmoni akan terwujud.

Program Keluarga Berencana di Indonesia yang secara resmi diintegrasikan dalam program pembangunan sejak tahun 1970-an melalui didirikannya BKKBN, secara umum dapat dikatakan berhasil. Kelancaran dari program ditopang oleh perkembangan yang pesat dalam kemajuan sosial ekonomi, kemajuan pendidikan, bertambahnya mobilitas penduduk, bertambahnya wanita dalam angkatan kerja, meningkatnya pendapatan perkapita, dan lain-lain. Di samping itu, juga ditopang oleh stabilitas politik dan komitmen pemerintah yang besar terhadap program ini. Media massa, jaringan jalan, transportasi, jumlah fasilitas kesehatan, maju dengan pesat (Geoffrey Mc Nicoll, 1983: 14).

Salah satu aset dari program pembangunan di Indonesia adalah struktur sosial tradisional yang masih tetap bertahan di desa dan unit yang lebih kecil dari desa. Unit tersebut adalah juga unit administrasi pemerintah. Berbagai instruksi yang datang dari pusat dapat mencapai desa dalam waktu yang relatif singkat dan menyusupi seluruh pelosok tanah air. Program itu kemudian diimplementasikan di tingkat desa dan dusun. Tidak adanya lembaga seperti itu untuk dijadikan ujung tombak merupakan penghalang yang penting di berbagai negara seperti umpamanya di India, Nigeria, dan lain-lain.

\section{E. Kesimpulan}

Pada bagian penutup ini dapat disimpulkan temuan-temuan pokok sebagai berikut: (1) Bahwa selama ini program Keluarga Berencana di Desa Panggungharjo dilaksanakan dengan baik dan atau bahkan telah menjadi tradisi masyarakat atau sudah terinternalisasi berdasarkan kesadaran masyarakat bersangkutan akan pentingnya KB, (2) Terhadap program Keluarga Berencana, baik masyarakat, tokoh masyarakat, maupun para tenaga ahli kesehatan persepsinya adalah positif sehingga dalam hal berpartisipasinya juga cukup tinggi, (3) Bentuk-bentuk partisipasi masyarakat terhadap program Keluarga Berencana terbatas pada pengertian dan pemahaman mereka tentang program Keluarga Berencana. Masyarakat yang paling berpartisipasi adalah mereka yang usia produktif. Sedangkan partisipasi petugas puskesmas adalah 
memberikan pelayanan terhadap pelaksanaan program. Sementara tokoh masyarakat dan perangkat desa terbatas pada memberikan himbuan dan fasilitas desa untuk kegiatan penyuluhan Keluarga Berencana, baik yang dilakukan oleh BKKBN, petugas kesehatan, maupun TP PKK oleh Dasa Wisma, dan (4) Kaitan antara persepsi dan partisipasi sangat berkaitan dengan latar belakang ekonomi, budaya, dan sosialnya. Karakteristik kehidupan yang masih sangat sederhana, mengkondisikan perilaku yang sederhana pula dalam kehidupan sehari-hari.

Di dalam program keluarga berencana terdapat dua kegiatan pokok. Pertama adalah menyadarkan masyarakat akan makna dan pentingnya memiliki keluarga kecil tapi bahagia. Hal ini pada umumnya dilakukan oleh BKKBN bekerja sama dengan unsur-unsur penerangan dan pelayanan kesehatan. Kedua adalah pelayanan kesehatan, memberikan obat dengan berbagai intervensi medik, agar reproduksi manusia itu diatur, cukup dua anak. Inilah tugas departemen kesehatan terhadap program KB baik menyangkut aspek kependudukannya maupun kesehatannya. Sedangkan Pusat Kesehatan Masyarakat (Puskesmas) dalam pelayanan kesehatan merupakan pos terdepan. Tugasnya ada tiga yaitu: menjadi pusat pelayanan kesehatan profesional; pusat pengembangan peranserta masyarakat dalam keikutsertaan membangun sendiri kesehatannya; dan pusat pembangunan kesehatan di wilayahnya.

Kita menyadari bahwa keberhasilan pelaksanaan programprogram kesejahteraan keluarga sangat ditentukan oleh adanya keterpaduan antara gerakan keswadayaan dan partisipasi masyarakat dengan bimbingan dan fasilitasi teknis dari berbagai instansi/lembaga terkait, yang terwadahi dalam dewan penyantun tim penggerak PKK. Informasi secara garis besar tentang posisi dan peranan gerakan PKK seperti itu, sesungguhnya sudah dapat menggambarkan betapa strategisnya fungsi TP PKK beserta kaderkader PKK yang tersebar diseluruh pelosok desa. TP PKK dapat menjadi perekat antara fungsi-fungsi kemasyarakatan dan fungsifungsi pemerintahan. TP PKK juga dapat berperan sebagai unsur terdepan yang akan menggalang peran-serta masyarakat.
Pada akhirnya masih diperlukan penyuluhan oleh dinas kesehatan terkait tujuan yang sebenarnya tentang program Keluarga Berencana, sehingga dalam pelaksanaannya dapat berjalan dengan baik, dan tidak disalahgunakan, terhadap pimpinan desa dan tokoh masyarakat perlu partisipasi yang lebih aktif agar pelaksanaan program dapat berjalan dengan baik, baik partisipasi dalam bentuk dukungan dana, maupun dalam hal yang menyangkut fasilitas, serta pada seluruh warga masyarakat untuk memahami betapa pentingnya arti kemandirian dan kesehatan bagi kelangsungan kehidupan, dan hal tersebut tidak saja menyangkut kesehatan dan perkembangan personal saja, melainkan juga kesehatan seluruh masyarakat.

\section{Daftar Pustaka}

Davidoff, LL. 1988. "Introduction To Psychology", alih bahasa Mari Juniati, Psikologi Suatu Pengantar Jilid I. Jakarta: Erlangga.

Departemen Pendidikan dan Kebudayaan, 1995. Kamus Besar Bahasa Indonesia Edisi Kedua. Jakarta: Balai Pustaka.

Hamijoyo, Santoso, S. dan A. Iskandar. 1974. Partisipasi Masyarakat, Seminar Pembangunan Kabupaten Bandung Dalam Sosiologi Pembangunan. Bandung.

Mubyarto. 1984. Strategi Pembangunan Pedesaan. Yogyakarta: P3PKUGM.

Mukti Ali, Prof. 1971. Agama dan Keluarga Berencana. Jakarta: BKKBN.

Ndraha, Talizidulu. 1990. Pembangunan Masyarakat Mempersiapkan Mayarakat Tinggal Landas. Jakarta: Ribeka Cipta.

Krippendorff, Klaus. 1991. Content Analysis: Introduction Its Theory and Methodology", Alih Bahasa Farid Wajidi, Analisis Isi: Pengantar Teori dan Metodologi. Jakarta: Rajawali.

Miles, M.B. and Huberman, A.M. 1984. Qualitative Data Analysis: A Sourcebook of New Methods. Beverly Hills CA: Sage Publications.

Moleong, L.J. 1999. Metodologi Penelitian Kualitatif. Bandung: Remaja Rosdakarya.

DIMENSIA, Volume 2, No. 1, Maret 2008 
Muhadjir, Noeng. 1996. Metodologi Penelitian Kualitatif. Yogyakarta: Rake Sarasin.

Patton, M.Q. 1980. Qualitative Evaluation Methods. Beverly Hills, CA.: Sage Publication.

Spradley, J.P. 1980. Participant Observation. New York, N.Y: holt, Rinehart, and Winston.

Sutopo, H.B. 1995. Kritik Seni Holistik Sebagai Model Pendekatan Penelitian Kualitatif. Surakarta: UNS Press.

Sutopo, H.B. 1996. Metodologi Penelitian Kualitatif. Surakarta: Jurusan Seni Rupa Fakultas Sastra UNS.

Suwarjono Surjaningrat. 1972. Masalah Kependudukan dan Pelaksanaan Keluarga Perencana Di Indonesia. Jakarta: BKKBN.

Thoha, Miftah. Tanpa tahun. Birokrasi Pembangunan Desa Partisipasi Rakyat. Makalah Lepas.

Waluyo, H.J. 2000. "Hermeneutik Sebagai Pusat Pendekatan Kualitatif", dalam Historika, No.11. Surakarta: PPS UNJ KPK UNS.

Yin, R.K. 1987. Case Study Research: Design and Methods. Beverly Hills, CA: Sage Publication. 